\title{
Cities and their hinterlands 10 years on: Local and regional governance still under debate
}

\author{
Tony Gore* \\ Sheffield Hallam University
}

\begin{abstract}
This paper reviews changes over the last 10 years in the governance arrangements and processes involved in sub-national economic development and cross-boundary collaboration. It begins with a summary of the institutional changes in the main countries of the UK, in the dual context of fiscal retrenchment and neo-liberal deregulation. The picture that emerges is one of a confused patchwork in England; incremental modifications in Scotland; and embryonic developments in Wales. This is then contrasted with a range of experiences in other countries, involving wholesale recentralisation and a sidelining of local and regional institutions at one end of the spectrum, to resistance to restructuring through repurposing, increased mutual collaboration and improved management at the other. However, enhanced economic links and benefits do not automatically flow from any particular form of rescaled governance arrangements. As our original article found, the key ingredients are robust and inclusive political and decision-making processes, a suite of appropriate policy instruments and deployment of sufficient resources to ensure that they have an effect. The paper also concludes that a more comprehensive theoretical framework is needed to advance understanding of what lies behind different forms of state governance rescaling, and what makes a given instance more (or less) effective than another.
\end{abstract}

Keywords: Administrative geography; collaborative governance; economic development; international comparisons; state rescaling.

\section{Introduction}

Ten years ago with my colleague Steve Fothergill I drew together relevant findings from our research for the Joseph Rowntree Foundation on the relative strength of connections between three former coalfield areas and their neighbouring cities (Central Valleys-Cardiff; Lothians-Edinburgh; and South Yorkshire-Sheffield) for the first volume of PPP. Our paper, Cities and their hinterlands: How much do governance structures really matter? (Gore and Fothergill, 2007) examined the extent to which these adjacent localities had developed collaborative governance structures and associated coordinating mechanisms, and whether their existence could be linked to improved economic outcomes such as employment take-up and business development. What we found was that there was no particular link between the extent of cross-boundary cooperation in territorial government and economic links and trends across the respective jurisdictions. Where such governance arrangements were in place, notably 
in South Yorkshire, the focus tended to be on reconciling competing claims between localities and thus on fostering polycentric development rather than agglomerative growth. While the places studied were variously beneficiaries or prisoners of their distinctive economic and transport geographies, at the same time levels of public funding and the suite of policy tools through which these monies were distributed emerged as being far more significant in an area's trajectory than reformed governance structures (see also Gore et al., 2007). Inevitably much has happened in the economic and political spheres since then, and this paper provides a welcome opportunity to revisit our findings and to explore wider implications and associated developments.

The original article was written at the time of lively debate around the most strategic scale for sub-national economic development in the UK, epitomised by the strong lobbying by the Core Cities Group for a switch from the Labour government's large and sprawling standard regions to more tightly defined city-regions, heralded as the 'drivers of economic growth' and promoted as aligning with 'natural' or 'functional' economic areas (see, for example, Core Cities Working Group, 2004; also Harrison, 2012). However, just covering the main urban conurbations in England meant that large rural tracts and numerous medium and small towns and cities fell outside these city regions, prompting calls for equal priority for county areas from their own lobbying wings, and critiques from academic observers on the basis of fragmentation, incoherence, inequity and a danger of 'crowding out' interests and potentials in non-priority areas (Pemberton and Shaw, 2012; Pike and Tomaney, 2009; Shaw and Greenhalgh, 2010). In response the government's Sub National Review represented an archetypal hedging of bets, with standard regions retained and the city regions and county areas nested within them encouraged to formulate joint economic development strategies and plans (HM Treasury et al., 2007).

Since then the debate has continued to rage and alternative spatial formulations have emerged, often in parallel and with varying fortunes in different parts of the country. This patchwork in part reflects the inherent difficulties of coordinating multiple organisations across different jurisdictions and the key ingredients required to make such arrangements work, a central issue which we noted back in 2007. It also reflects important changes in the economic, political and institutional landscape of the UK. Following the global financial crisis of 2008, the ethos of government has been one of austerity and fiscal retrenchment, with successive Labour, Coalition and Conservative administrations overseeing some of the severest budgetary reductions for welfare and local public services witnessed outside wartime (see for example Beatty and Fothergill, 2013; 2016; Hastings et al., 2015). Yet at the same time as centralised fiscal control has been tightening year by year, the devolution of powers to Scotland, Wales and to a lesser extent Northern Ireland has continued, and an increase in autonomy in a limited range of policy domains has also been afforded to selected English city regions. The latter in particular has been contingent upon the adoption of revised local governance arrangements, a trait that has also come into play to varying degrees in the devolved nations as well. Indeed, the spectrum of local and regional governance changes in response to fiscal crisis, from 'centrally orchestrated' restructuring (Harrison, 2008) at one end to local voluntaristic collaboration at the other, emerges as a recurring theme in the review that follows.

The remainder of this paper begins, firstly, with a summary of the nature of and background to these institutional changes across the UK, including any research findings available on their impact or effectiveness. However, in keeping abreast of current intelligence on the geography of governance the realisation has dawned of a need to broaden attention from the acutely UK-centric nature of much of the writing on this topic (including our original article). The second section, therefore, presents an international perspective on the subject. Certainly, it is clear that many other countries 
have undergone, or at least have faced strident calls for, some form of local and/or regional governance restructuring, and not only those inhabiting the 'Western' economic/political sphere. The summary of key findings of international research features the intertwined themes of expenditure savings and power balance shifts, often to the detriment of local service provision and promotion of regional economic development, although there are isolated examples of resistance. This general reduction in local and regional capacities then casts some doubt on the extent to which the claimed economic benefits do actually flow from these rescaled and collaborative realignments, even where it is accompanied by a devolution of powers. Thus the fourth section seeks to elaborate on this aspect of the debate by examining the limited research available on the effects of such governance reforms. The conclusion then rounds matters off with a call for a fusing of theoretical frameworks from the respective traditions of regional geography and political science, and the application of a more comprehensive perspective in as wide a variety of empirical settings as possible.

\section{New institutional frameworks}

In 2009 the call by English county councils to adopt the county scale in mostly rural areas as a complement to the main city regions was partially successful, with eight new county scale unitary authorities replacing the erstwhile two-tier system of county and district councils dating from the last wholesale local government reorganisation in the UK in 1974. In the process 36 local authority (or lower tier district councils) disappeared (see Fothergill and Gore, 2011). At the same time, the switch did not happen in all counties where amalgamation proposals had been made; here affected districts unwilling to be subsumed in the new arrangements effectively blocked the restructure (e.g., in Cumbria). Central considerations for these authorities were the fear of being governed entirely from a distant centre, and a history of previous battles for influence between the two tiers. Differences in party political representation no doubt also played a part. Nevertheless, the argument promoting amalgamation has continued, with current proposals affecting Dorset and Suffolk amongst others. Perhaps the most significant development here, however, is that these arguments are now couched much more in terms of public expenditure savings rather than alignment with, or boosting of, local economies (EY, 2016; County Councils Network, 2016; Blond et al., 2017). In addition, at a more prosaic level, the vast majority of local authorities now share certain 'back office' functions with one or more of their neighbours (Sandford, 2012; Local Government Association, 2016).

However, by far the biggest change in England has been the replacement of the nine standard regions and their Development Agencies by 39 Local Enterprise Partnerships (LEPs), ${ }^{1}$ comprising representatives from public, private and voluntary sectors and charged with promoting the economic development of their respective territories. Area boundaries were set on the basis of combinations of local authorities, fixed initially in terms of established city regions for the metropolitan cores and traditional counties for the rural parts. However, the desire of some counties to link together resulted in some voluntary amalgamations, while the prospect of an excessive number of LEPs prompted the government to engineer at least one forced marriage, with East Sussex, Essex and Kent on either side of the Thames estuary unwillingly corralled together under the South East LEP. This strong sense of compulsion that reduced 62 partnership bids to 39 designated LEP areas prompted Harrison (2011: 2) to observe that in many cases the partnerships were "maiden coalitions of the obliged" rather than "experienced coalitions of the willing". The pattern was also further disrupted by permitting several local authority districts to belong to more than one LEP. While this points to a certain political astuteness on the part of the protagonists, in 
seeking to maximise the benefits from the new framework, it has also been criticised for serving to cast doubt upon the rationale for LEPs providing a better 'fit' to 'functional economic areas' (Townsend, 2012). At the same time, the built-in flexibility it provides might help in places where the footprints of such areas overlap at the edges.

One of the main initial critiques of LEPs in their early days was the lack of resources and capacity at their disposal to intervene directly in their local economies, for example through infrastructure additions or renewals (Shutt et al., 2012; Ayres and Stafford, 2014; Bowden and Liddle, 2018). Thus, in the first five years central government funding to all LEPs amounted to around $£ 1.5$ billion (an average of under $£ 40$ million per area). Not surprisingly, during this time the focus tended to be on strategic steering of partners' activities, particularly local authorities. It quickly became apparent that the severe restrictions on the latter's expenditure (including loss of key personnel) meant that few of these plans were being realised. Since 2015, therefore, the LEPs have received increased funding through the Local Growth Fund and its associated Growth Deals, to the tune of $£ 12$ billion between 2015-16 and 2020-21 (an average of over $£ 300$ million per LEP) (National Audit Office, 2016a: 6). However, the continuing lack of appropriate staffing and skill levels within LEPs led not only to an underspend of this funding allocation in the first year, but also to an emphasis on implementing 'shovelready' projects that were not necessarily optimal in terms of fostering local economic development (op.cit: 7), and continued reliance on much depleted local authority staff bases for intelligence and expertise (Bentley et al., 2017). The generally narrow range of business sectors represented on most LEP boards and the low levels of oversight and accountability at both regional and national scales has prompted fears of 'capture' by specific interests, particularly those involved in property development (House of Commons Committee of Public Accounts, 2016; House of Commons Business, Energy and Industrial Strategy Committee, 2017). On the plus side, however, research undertaken for the Royal Town Planning Institute did reveal certain strengths around the coordination of often disconnected policy areas such as planning, housing, enterprise and employment, and the potential role of LEPs as brokers between the different public and private interests involved (Pugalis et al., 2015).

The problem with capacity has militated against LEPs becoming the key players in rolling out central government's selective devolution of powers to English metropolitan areas. Instead the preferred mechanism has become a series of Combined Authorities (legally constituted government arrangements between two or more local authorities for operating statutory functions transferred to them from the centre), most overseen by an elected Mayor. The first to be established, Greater Manchester, emerged in 2011; since then, eight others have followed, although that for the Sheffield City Region has been in abeyance following a legal challenge over the participation of local authorities in north Derbyshire by Derbyshire County Council. This Combined Authority is now focused on the core South Yorkshire part of this area, with the others linked as 'non-constituent' members. Within that core, the high degree of cooperation we noted at the time of our JRF case study appears to have dissipated somewhat, partly due to the diminution of resources available following the reduction in European Structural Funds support, and partly due to the perception that Sheffield may be seeking to be the key location, instead of pursuing the previous polycentric trajectory that helped keep all players at the table (Gore, 2008; see also Henderson, 2015, for a parallel example in the Black Country). In response, two of the four local authorities in the area are currently exploring a wider cross-regional set-up which would cover 15 of the 20 council areas in Yorkshire (Perraudin, 2017).

The central role assigned to the nine Combined Authorities established to date is the agreement and implementation of most of the English Devolution Deals approved by central government (just one county, Cornwall, has entered into this type of 
arrangement). These deals provide greater autonomy at city region or county level over a variable range of functions and policy domains. In the broadest terms this includes (in no particular order, and with a different mix in each area): transport, business support, further education and adult skills, housing and planning, health and social care and co-commissioning of employment support (National Audit Office, 2016b: 7). There are also different sized pots of money associated with these new powers. Although Combined Authorities are rooted in the democratically elected member councils which have long histories of local public management, they still remain relatively untested and experimental. In particular some areas have the benefit of long and productive joint working (e.g., Greater Manchester), whereas others are starting from a much lower base (op.cit: 13).

Much will depend on the extent to which those involved are able to build up or draw upon 'network capital' (trust and understanding built up over time through cooperation and joint working). Those in the north of England are also hypothetically linked together by the concept of promoting the 'Northern Powerhouse'. This is an attempt to bring together infrastructure investment projects across the north of England so that they provide a major economic boost that will help kick-start a rebalancing of the national economy. However, it remains a rather disjointed concept, being described by Lee (2017: 479-480) as "fuzzy (and) problematic...., (neither) a defined institution or plan, but a vague idea which has shaped government policy and political rhetoric."

Agreeing such specific funding packages as Growth and Devolution Deals has become a favoured mechanism of UK central government as part of its austerity agenda, not only as a means of securing greater control over directions of local expenditure, but also as a catalyst for cross-boundary coordination. In many ways these were pioneered by the earlier City Deals of the Coalition, with 27 of these across two waves, the first tranche for the core city regions in England, with the second more tailored towards smaller city/county combinations (and perhaps instructively not generally on the basis of LEP areas). The Wave 1 agreements have been estimated to involve $£ 2.3$ billion in expenditure over a 30 year period, focused mainly on infrastructure, transport, skills development and business support as a means of stimulating local and regional economic growth. While any economic impact is likely to be long term (National Audit Office, 2015), they have not been without their critics. Thus, O'Brien and Pike (2015: R14) concluded that they embodied "...a process of dealmaking founded upon territorial competition and negotiation between central national and local actors unequally endowed with information and resources, (leading) to highly imbalanced and inequitable outcomes across the UK. As a template for public policymaking in an emergent and decentralising context, (such) deal-making raises substantive and unresolved issues for governance ...."

As implied, this form of funding is not confined to the English case, even though most of the devolutionary and forced collaborative action has been concentrated there. There have been City Deals in Scotland and Wales too (more accurately 'City Region' Deals in Scotland), with strong prospects of one for Belfast in Northern Ireland being concluded soon as well. Two of these agreements cover the other case study areas used in our original research: Cardiff Capital Region on the one hand, and Edinburgh and South East Scotland on the other. Both of these extend beyond the limits of our city-coalfield delimitation, incorporating 10 and six local authority areas respectively. For Cardiff and the Valleys, not surprisingly in view of our findings, the focus is on transport and infrastructure to improve connectivity between the constituent areas, with a $£ 1.2$ billion fund in place over 20 years aimed especially at the practical development of the South East Wales Metro transit concept (National Assembly for Wales, 2017). As yet there are no details about what form of transport technology might be appropriate for this, or, more pertinently, affordable in terms of the available 
budget. At least the City Deal appears to be fostering greater cross-boundary collaboration, given that its implementation will be overseen by an inter-organisational Regional Board. In contrast the emphasis of the Edinburgh City Deal is more evenhanded, with some improvement in transport links to enable residents of the subregion to access economic opportunities, but with an equal share given to spreading benefits more widely through investment in housing, business, innovation and skills in hinterland areas.

Interestingly, Scotland and Wales have had different experiences as far as the restructuring of local government is concerned, even though both moved to a system of unitary authorities at the same time in 1996. Thus, in Scotland there have been few calls for any further formal reorganisation, although the four main cities are in process of developing city regional arrangements for planning and economic development purposes. These are being mirrored by larger combined units for similar purposes in the more remote rural parts of the country too. In contrast, since the establishment of the devolved Welsh Assembly in 1999 there have been several attempts at rationalising the operation of local government in Wales, focusing initially on shared service provision, cross-boundary strategic collaboration and joint working between a range of public institutions (lorwerth, 2013). The approach was encapsulated in the Beecham Report of 2006, and manifested in the Local Service Boards set up from mid2007 onwards. One of these, the South East Wales Shared Service Project, covered what is now called the Cardiff Capital Region, but came into existence just after our JRF research study had finished. It is perhaps instructive to note that, rather than acting as a vehicle for a more balanced spread of economic development and improved access to opportunities, the project's aims of increased joint working and shared back office functions were couched primarily in terms of the $£ 45$ million that would be saved by such actions.

The impetus to curb expenditure levels is in fact a recurring feature of local governance debates; they are not just a product of post-crisis austerity policies, although of course these have thrown them into much sharper relief. Indeed, in Wales austerity heralded a shift from an emphasis on inter-organisational collaboration to a search for local authority mergers. First floated by the Williams Commission of 2013, the 22 councils were invited to pursue amalgamation on a voluntary basis. In spite of widespread discussions, none of the suggested combinations came to pass. This was then followed in 2015 by the drafting but subsequent abandonment of legislative proposals to reduce the number of local authorities to eight or nine. The current proposition is contained in a White Paper which seeks to cut through the impasse by combining mandatory regional working in domains such as economic development, workforce skills, planning, transport, education and social services with flexibility over the precise footprint over which these shared services are provided. While voluntary council mergers are still not ruled out, the stress is clearly on forced collaboration, with the prospect of a new financing model giving it further strength (Welsh Government/Llywodraeth Cymru, 2017).

These difficulties in Wales provide something of an extreme microcosm of the issues at work in seeking greater efficiency and effectiveness in governing localities and regions. The other UK examples quoted in this section also point towards political and historical dimensions as the fulcrum around which attempts at reform must turn. Thus, the pre-existing scalar and spatial partitioning of power can create resistant nodes which even hierarchical authorities find tough to unpick. In a relatively small country like Wales (but also across the UK in general) these nodes also find further strength through party political and elite networks across different levels of government; and of course their key members in terms of policy implementation (local politicians) need to be assured that any new system will still enable them to bring 
benefits to local residents. It seems that it is only where such local nodes are weakly developed, or where national governments have centralised power to virtually monopolistic levels that wholesale top-down changes are likely to be feasible.

\section{International perspectives}

In spite of the widespread commitment to multi-level governance across the European Union, some of its members in fact provide cases where national governments have imposed far-reaching reforms that have reduced the power and capacity of local government units. Nor has this been merely part of the fall-out from the global banking crisis of 2008 and the ensuing recession, with far-reaching local government restructuring across many of the Scandinavian countries during the 2000s, for example (Lidström, 2010; Mouritzen, 2010; Sandberg, 2010).

That said, the fiscal problems facing national governments after 2008 undoubtedly brought the issue into full focus, particularly in relatively young democracies in eastern Europe. Thus, in Hungary recentralisation of power and resource allocation has been accompanied by a fragmentation of local government, the disappearance of any mesolevel regional authority and consequently a lack of capacity at sub-national scale in terms of both service delivery and promotion of local development (Kovács, 2014; 2017). That said, there appears to be little political or popular support for greater decentralisation in the country. Instead, there has been a move to a stronger central state, but along more managerial than 'neo-Weberian' lines, involving strong reliance on markets and the private sector. Similar reductions in local and regional capacity as a response to the post-2008 fiscal crisis and its political fall-out have also been noted in Belarus (Sarazhinsky, 2014), Slovakia (Buček and Sopkuliak, 2014; Halás and Klapka, 2017) and Portugal (Nunes Silva, 2014). In other instances the focus has been on the reduction in the number of local government units by means of forced mergers, as has been the case in Italy (Armondi, 2017). Where existing governance arrangements are more resistant to change this type of 'upward' rescaling appears to have involved less entrenched targets: the establishment of a smaller set of merged 'super-regions' in France in 2016 is a case in point (Anon., 2016). The architects of such mergers or other forms of rescaling generally claim that they will perforce bring public expenditure savings in their train, although this is beginning to be disputed, as shown in recent work on Denmark by Blom-Hansen et al. (2016).

For the most part, academic attention has focused on cooperation and coordination between existing municipal authorities at a city region or metropolitan scale, comparing and contrasting European and North American experiences in the process. Thus, Herrschel (2014) examined four cities in Canada and the USA (Atlanta, Detroit, Seattle and Vancouver) and three in Europe (Hamburg, Lyon and Turin) in terms of their governance processes and policy-making practices. He concluded that there is a complex interaction of political, economic and social factors that produces placespecific 'local-regional' governance constructs shot through with 'scalar ambivalence'. This interaction is played out in the power dynamics between state interests and requirements on the one hand, and the spatial selectivity of globalised capital flows on the other. The democratic dimension in fact emerged as a key determinant of governance modes in particular city regions, with legitimacy crucial in allowing (or circumscribing) local politicians' scope for collaboration with neighbouring authorities. What the evidence implies is that there is "....no automatic 'best practice' in scalar governance: what works - and is accepted - ....depends on the particular socio-cultural and political-economic local 'milieu' at a particular point in time." (op.cit.: 160) 
A similar conclusion was reached by Hamilton (2014) in his study tracing how local government in metropolitan areas of the USA have responded to continuing demands to accommodate growth and expansion. While he unearthed examples of both restructuring and amalgamation, the most prominent trend is towards collaboration across polycentric urban regions (see also Wachsmuth, 2017). He notes that voluntary moves in this direction have become increasingly important as an alternative to wholesale institutional readjustment. Interestingly, this has been especially the case where private and voluntary sector representatives are involved in governance. The approach seems to act as a bridge between policy imperatives handed down from State and Federal governments and the tendency towards both economic and political polycentricity in metropolitan areas. Similar driving forces also emerged from the work of Nelles (2013) looking at two Canadian and two German cities. Her study also distilled the centrality of civic capital and committed leadership as crucial catalysts for increased cooperation. This in turn highlights the importance of local agents and their actions, especially those acting as 'place leaders'. By way of example, a study by Sotarauta and Beer (2017) revealed differential patterns of such leadership in Australia and Finland, conditioned by factors such as the relative fiscal strength of local government, the degree of openness and possible local independence within political structures and networks, and access to additional, often ad hoc resources.

Although the focus of most studies of local governance reform has been on Europe and North America, the underlying pressures are not the exclusive preserve of Western hemisphere nations. Thus, a recent article by Lim (2017) on state rescaling and policy experimentation in post-Mao China highlights the fact that, despite the clear differences in political and cultural context, local restructuring and inter-municipal collaboration have helped to reproduce, or even reinforce, the national scale as the prime regulatory platform. Moreover, as we argued 10 years ago, the evidence suggests that there is no reason why the socio-economic forces at work should inevitably privilege the city region as the local/regional regulatory scale of choice. As we have seen in the UK, this primacy has been disputed from the beginning by certain voices, but more recently the dissatisfaction has become much stronger, leading to a re-promotion of the county scale at one end of the spectrum and a possible 'return to the region' at the other.

From the extensive literature reviewed so far there is a danger of concluding that such local and regional reorientations are in some way inevitable in the current context. However, this would ignore the experience of those countries where the focus has been on improved fiscal management and service delivery within the same structures, or where attempted rescaling has been met with a certain degree of effective resistance. Spain provides a good example of the latter, with an attempt by central government to concentrate municipal service provision at the provincial or even regional scale foundering on the back of popular opposition, inadequate alternative capacity and lack of political will on the part of many of the autonomous regions (Navarro and Velasco, 2015). Over the same period the targeted reduction in the number of inter-municipal service delivery and developmental associations (or 'mancomunidades') and the upward transfer of their functions has similarly failed to make headway save in a couple of the more rural regions (Gore, 2017). It is instructive to note that this collaborative form of provision also acted as a buffer against the pressures for privatisation during the 'new public management' push of the 2000s (Bel and Fageda, 2008). As always, the Spanish experience is overlain by issues of what Calzada (2017) has usefully conceptualised as quasi-federalism and pluri-nationality, with the current constitutional crisis surrounding Catalonia just the latest of these internal tensions. The historic intractability of such divisions was encapsulated back in the 1930s by the politician-philosopher José Ortega y Gasset as "a problem that cannot be resolved, (but).... only steered along" (quoted in Minder, 2017: 302). Without underplaying the 
severity of the issues involved in the Catalan case, this dictum can be seen to apply to many of the examples cited so far in this review.

\section{Economic benefits of collaboration}

In the original article 10 years ago our research posited an inverse relationship between the extent of collaborative governance and the strength of economic ties between adjacent areas. Of course, on the basis of three case studies in a particular country at a given point in time, this can now be seen as rather an ambitious conclusion, or at least one that perhaps should not be generalised beyond the UK. Having said that, there have been few further studies that have attempted to examine this relationship. Indeed, a direct update of the original study has not been possible; it would be interesting to see whether the same sort of patterns persisted today. Nevertheless, current work by colleagues on labour market changes between 2010 and 2016 in 92 local authority districts classed as 'older industrial towns' has examined the extent to which outward commuting flows have linked these areas to their nearest big city. Preliminary results indicate that, while outward travel to work journeys from such towns have increased by around 12 per cent, in only two cases (Cardiff and Manchester) did there appear to be growing dependence of an older industrial hinterland on jobs in a nearby regional city (Beatty and Fothergill, 2018). In terms of devolved collaborative governance, arrangements around the former are still at the embryonic stage, as has already been mentioned, whereas Greater Manchester has been (and remains) at the forefront of the process. In other words, the lack of 'read off' between cross-boundary collaboration and economic links that we encountered ten years ago still apparently persists.

Otherwise, only one piece of research has emerged that attempted to assess the economic impact of collaboration between local government units across their collective region. This study involved broad statistical regression analysis across over 100 North American metropolitan regions, combined with detailed case studies of three of these (Greater Montreal, the San Francisco Bay Area and the Buffalo-Niagara trans-border conurbation) in order to tease out the effects of functional cross-boundary collaboration on socio-economic integration, economic competitiveness and environmental protection (Thibert, 2015).

The results indicate that purely 'bottom-up' collaboration is unlikely to make much difference in terms of issues like business promotion and income disparities, although it can improve the delivery of basic services. Some form of involvement by higher level state institutions is required for detectable economic effects to emerge, not only in providing additional resources to help implement a particular policy initiative, but also in giving a more legitimate mandate for the intervention. This role involves a mixture of facilitation, enforcement and negotiation involving all parties. At root, however, the key requirement is for a suite of policy tools to be developed to engage directly with the complexity of the problem(s) being addressed. If this does not emerge there is a danger that collaboration might merely be effective in "weaving ties" between actors, contributing to the growth of civic and network capital and fostering further collaboration, without having much impact on economic outcomes across the region as a whole. 


\section{Conclusions}

It is certainly gratifying that a much more detailed study than our own, albeit in a different socio-political context, should arrive at such broadly similar conclusions as we did 10 years ago. In that article our final comment was that any rescaled or collaborative governance arrangements need to be supported by sufficiently robust institutional arrangements and political processes (see also Rodríguez-Pose, 2013). However, it appears from the plethora of varying cases of local government restructuring, rescaling and cross-boundary collaboration across the globe quoted in this paper that this tends to be the exception rather than the rule. In other words, tinkering with sub-national governance structures, often as an exercise in political power but without sufficient attention to capacities and capabilities, is not just some strange "UK addiction", as claimed by Elcock et al. (2010); the trend has been shared by many other countries across the world, and there is little sign of the calls diminishing.

The reasons for the continuing restructuring drive are rather harder to fathom, despite the copious literature on the topic. Indeed, the provenance of these writings relates to two broad traditions, namely regional and political geography on the one hand, and political science and public administration on the other. The former tends to emphasise administrative structures, socio-economic context and political decisionmaking, whilst the latter mainly focuses on the nature, interests and capacities of the participating actors, the degree of agency they are able to deploy, and the interactive processes in which they are involved. Until recently there has been little crossover between the two, but this may be starting to change. Thus, Jessop (2016), one of the leading analysts on the spatiality of the state, has sought to further enhance the 'territory, place, scale, networks' (TPSN) heuristic framework previously developed with colleagues (Jessop et al., 2008) by adding a wider set of social and political dimensions such as governance arrangements, flows of goods, information and people, decisionmaking processes and the like. From the other direction, researchers interested in networked and collaborative forms of governance more broadly have begun to incorporate a scalar dimension into their work, especially in exploring tensions across scales or between multiple scales ${ }^{2}$ (Ansell and Torfing, 2015).

To date, however, there has been limited empirical application of either the TPSN or the scale-informed interactive governance frameworks in the context of rescaled governance arrangements, with Lim (2017) being one of the few exceptions. Several bridges will be required to link the two together to provide a more overarching theoretical apparatus. Given its likely size and complexity, empirical application of any composite framework will certainly pose challenges to researchers in the field. Yet without this type of theory-informed investigation our understanding of the forces that keep the moving carpet of state spatiality in motion will not improve. However, all being well I will be able to report on some advances along these lines in PPP once again ten years from now.

\section{Notes}

1 Now 38, following the folding of Northamptonshire LEP into South East Midlands in mid-2017.

2 It is worth noting that this refers not just to spatial or geographical scale, but also temporal, numerical/quantitative and functional scales too. 
p. 160. Cities and their hinterlands 10 years on: Local and regional governance still under debate

* Correspondence address: Dr Tony Gore, CRESR, Sheffield Hallam University, Unit 10, Science Park, Howard Street, Sheffield, S1 1WB. Email: t.gore@shu.ac.uk

\section{References}

Anon. (2016) New map of France finalized as regions settle on names. The Local, [online] Available at: https://www.thelocal.fr/20160628/new-map-of-francefinalized-as-regions-settle-on-names [Accessed: 09/12/2017]

Ansell, C. and Torfing, J. (2015) How does collaborative governance scale? Policy and Politics, 43, 3, 315-329. DOI: 10.1332/0305573X14353344872935

Armondi, S. (2017) State rescaling and new metropolitan space in the age of austerity: Evidence from Italy. Geoforum, 81, 174-179. DOI: 10.1016/j.geoforum.2017.03.008

Ayres, S. and Stafford, I. (2014) Managing Complexity and Uncertainty in Regional Governance Networks: A Critical Analysis of State Rescaling in England. Regional Studies, 48, 1, 219-235. DOI: 10.1080/00343404.2012.672727

Beatty C. and Fothergill, S. (2013) Hitting the poorest places hardest: The local and regional impact of welfare reform. Sheffield: Centre for Regional Economic and Social Research, Sheffield Hallam University.

Beatty C. and Fothergill, S. (2016) The uneven impact of welfare reform: The financial losses to places and people. Sheffield: Centre for Regional Economic and Social Research, Sheffield Hallam University.

Beatty C. and Fothergill, S. (2018 forthcoming) Labour Market Flows in Britain's Older Industrial Towns. Sheffield: Centre for Regional Economic and Social Research, Sheffield Hallam University.

Bel. G. and Fageda, X. (2008) Local privatization, intermunicipal cooperation, transaction costs and political interests: Evidence from Spain. Journal of Economic and Political Reform, 11, 45-65.

Bentley, G., Pugalis, L. and Shutt, J. (2017) Leadership and systems of governance: The constraints on the scope for leadership of place-based development in subnational territories. Regional Studies, 51 2, 194-209. DOI: 10.1080/00343404.2016.1181261

Blom-Hansen, J., Houlberg, K., Serritzlew, S. and Treisman, D. (2016) Jurisdiction Size and Local Government Policy Expenditure: Assessing the Effect of Municipal Amalgamation. American Political Sciences Review, 110, 4, 812-831. DOI: 10.1017/S000305541600320

Blond, P., Follett, T. and Morrin, M. (2017) Devo 2.0: The Case for Counties, Report for the County Councils Network. London: ResPublica.

Bowden, A. and Liddle, J. (2018) Evolving public sector roles in the leadership of placebased partnerships: from controlling to influencing policy? Regional Studies, 52, 1, 145-155. DOI: 10.1080/00343404.2017.1346369

Buček, J. and Sopkuliak, A. (2014) Local Self-government Finance During the 2008-11 Crisis. In: Nunes Silva, C. and Buček, J. (eds) Fiscal Austerity and Innovation in Local Governance in Europe. Farnham, Surrey: Ashgate, 7-30.

Calzada, I. (2017) Metropolitan and city-regional politics in the urban age: why does "(smart) devolution" matter? Palgrave Communications: Humanities/Social Sciences/Business, 1-17. DOI: 10.1057/palcomms.2017.94

Core Cities Working Group. (2004) Our Cities Are Back: Competitive Cities Make Prosperous Regions and Sustainable Communities, Third Report. London: Office of the Deputy Prime Minister.

County Councils Network (2016) A New Deal for Counties: Our Plan for Government. London: The County Councils Network. 
Elcock, H., Fenwick, J. and McMillan, J. (2010) The reorganization addiction in local government: unitary councils for England. Public Money and Management, 331338. DOI: 10.1080/09540962.2010.525000

EY. (2016) Independent Analysis of Governance Scenarios and Public Service Reform in County Areas, Report for the County Councils Network. London: Ernst and Young.

Fothergill, S. and Gore, T. (2011) The Statistical Bias against Unitary Counties: How local government reorganisation has hidden deprivation and threatens to strip authorities of funding. Sheffield: Centre for Regional Economic and Social Research, Sheffield Hallam University.

Gore, T. and Fothergill, S. (2007) Cities and their hinterlands: how much do governance structures really matter? People, Place and Policy Online, 1, 2, 55-68.

Gore, T., Fothergill, S., Hollywood, E., Lindsay, C., Morgan, K., Powell, R. and Upton, S. (2007) Coalfields and Neighbouring Cities: Economic Regeneration, Labour Markets and Governance. York: Joseph Rowntree Foundation/York Publishing.

Gore, T. (2008) Collaborative governance and territorial rescaling in the UK: a comparative study of two EU Structural Funds programmes, GeoJournal, 72, 5973. DOI: $10.1007 / \mathrm{s} 10708-008-9165-5$

Gore, T. (2017) Collaborative governance under siege: The disparate prospects of intermunicipal associations ('mancomunidades') in Spain. Presentation to the International Geographical Union Geography of Governance Commission Annual Conference, Local Governance in the New Urban Agenda, University of Salento, Lecce, Italy, 19th-21st October.

Halás, M. and Klapka, P. (2017) Functionality versus gerrymandering and nationalism in administrative geography: lessons from Slovakia. Regional Studies, 51, 10, 1568-1579. DOI: 10.1080/00343404.2017.1215602

Hamilton, D. (2014) Governing Metropolitan Areas: Growth and Change in a Networked Age. Abingdon, Oxon.: Routledge.

Harrison, J. (2008) Stating the Production of Scales: Centrally Orchestrated Regionalism, Regionally Orchestrated Centralism. International Journal of Urban and Regional Research, 32, 4, 922-941. DOI: 10.1111/1468 2427.2008.00815.x

Harrison, J. (2011) Local Enterprise Partnerships. Loughborough: Centre for Research in Identity, Governance, Society (CRIGS)/Globalization and World Cities (GaWC) Research Network, Loughborough University.

Harrison, J. (2012) Life after Regions? The Evolution of City-regionalism in England. Regional Studies, 46, 9, 1243-1259. DOI: 10.1080/00343404.2010.521148

Hastings, A., Bailey, N., Bramley, G., Gannon, M. and Watkins, D. (2015) The Cost of the Cuts: The Impact on Local Government and Poorer Communities. York: Joseph Rowntree Foundation. Available at: http://www.jrf.org.uk/sites/files/jrf/CostofCuts-Full.pdf

Henderson, S. (2015) From Sub-regional Networks to Sub-regional Localism: Experiences of Collaboration in England's Historical Black Country. Regional Studies, 49, 9, 1497-1513. DOI: 10.1080/00343404.2013.845655

Herrschel, T. (2014) Cities, State and Globalisation: City-Regional Governance in Europe and North America, Regions and Cities Series. Abingdon, Oxon.: Routledge.

Her Majesty's Treasury, Department for Business Enterprise and Regulatory Reform (DBERR), and Communities and Local Government (CLG) (2007) Review of subnational economic development and regeneration. Norwich: Office of Public Sector Information.

House of Commons Business, Energy and Industrial Strategy Committee (2017) Industrial Strategy: First Review: Second Report of Session 2016-17, Report HC616. London: House of Commons. Available at: 
p. 162. Cities and their hinterlands 10 years on: Local and regional governance still under debate

https://publications.parliament.uk/pa/cm201617/cmselect/cmbeis/616/616.p df [Accessed: 08/01/2017]

House of Commons Committee of Public Accounts (2016) Cities and local growth: Sixth Report of Session 2016-17, Report HC296. London: House of Commons. Available at: https://publications.parliament.uk/pa/cm201617/cmselect/cmpubacc/296/29 6.pdf [Accessed: 08/01/2017]

lorwerth, R. (2013) Public services reform: timeline of local government developments, Research Paper. Cardiff: National Assembly for Wales.

Jessop, B. (2016) Territory, Politics, Governance and Multispatial Metagovernance. Territory, Politics, Governance, 4, 1, 8-32. DOI: 10.1080/21622671.2015.1123173

Jessop, B., Brenner, N. and Jones, M. (2008) Theorizing sociospatial relations. Environment and Planning D: Society and Space, 26, 3, 389-401. DOI: 10.1068/d9107

Kovács, I. (2014) Failed Rescaling of Territorial Governance in Hungary: What Was The Gist? In: Nunes Silva, C. and Buček, J. (eds) Fiscal Austerity and Innovation in Local Governance in Europe. Farnham, Surrey: Ashgate: 95-111.

Kovács, I. (2017) The Changing Paradigm of Local Governance in Hungary, paper presented to the International Geographical Union Geography of Governance Commission Annual Conference, Local Governance in the New Urban Agenda, University of Salento, Lecce, Italy, $19^{\text {th }}-21^{\text {st }}$ October.

Lee, N. (2017) Powerhouse of cards? Understanding the 'Northern Powerhouse'. Regional Studies, 51, 3, 478-489. DOI: 10.1080/00343404.2016.1196289

Lidström, A. (2010) The Swedish Model under Stress: The Waning of the Egalitarian, Unitary State? In: Baldersheim, H. and Rose, L. (eds) Territorial Choice: The Politics of Boundaries and Borders. Basingstoke, Hants: Palgrave Macmillan, 6179.

Lim, K. F. (2017) State rescaling, policy experimentation and path dependency in postMao China: a dynamic analytical framework. Regional Studies, 51, 10, 15801593. DOI: 10.1080/00343404.2017.1330539

Local Government Association (2016) Stronger Together: Shared management in local government. London: LGA. Available at: https://www.local.gov.uk/sites/default/files/documents/stronger-togethershared--01e.pdf [Accessed: 11/12/2017]

Minder, R. (2017) The Struggle for Catalonia: Rebel Politics in Spain. London: Hurst and $\mathrm{Co}$.

Mouritzen, P. (2010) The Danish Revolution in Local Government: How and Why? In: Baldersheim, H. and Rose, L. (eds) Territorial Choice: The Politics of Boundaries and Borders. Basingstoke, Hants: Palgrave Macmillan: 21-41.

National Assembly for Wales (2017) City Deals and the Regional Economies of Wales. Report by the Economy, Infrastructure and Skills Committee. Cardiff: National Assembly for Wales. Available at: http://senedd.assembly.wales/mglssueHistoryHome.aspx?lld=18468 [Accessed: 09/12/2017]

National Audit Office (2015) Devolving responsibilities to cities in England: Wave 1 City Deals. Report HC266, Session 2015-16, London: National Audit Office. Available at: $\quad$ https://www.nao.org.uk/wp-content/uploads/2015/07/Devolvingresponsibilities-to-cities-in-England-Wave-One-City-Deals.pdf [Accessed: $11 / 12 / 2017]$

National Audit Office (2016a) Local Enterprise Partnerships. Report HC887, Session 2015-16, London: National Audit Office. Available at: https://www.nao.org.uk/wpcontent/uploads/2016/03/Local-Enterprise-Partnerships.pdf [Accessed $11 / 12 / 2017]$ 
National Audit Office (2016b) English devolution deals, Report HC948, Session 201516, London: National Audit Office. Available at: https://www.nao.org.uk/wpcontent/uploads/2016/04/English-devolution-deals.pdf [Accessed 11/12/2017]

Navarro, C. and Velasco, F. (2015) 'In wealth and in poverty?' The changing role of Spanish municipalities in implementing childcare policies. International Review of Administrative Sciences, 82, 2, 315-334. DOI: 10.1177/0020852315576707

Nelles, J. (2013) Cooperation and Capacity? Exploring the Sources and Limits of CityRegion Governance Partnerships. International Journal of Urban and Regional Research, 37, 4, 1349-1367. DOI: 10.1111/j.1468-2427.2012.01112.x

Nunes Silva, C. (2014) The Economic Adjustment Program Impact on Local Government Reform in Portugal. In: Nunes Silva, C. and Buček, J. (eds) Fiscal Austerity and Innovation in Local Governance in Europe. Farnham, Surrey: Ashgate, 31-47.

O'Brien, P. and Pike, A. (2015) City Deals, Decentralisation and the Governance of Local Infrastructure Funding and Financing in the UK. National Institute Economic Review, 233, 1, R14-R26.

Pemberton, S. and Shaw, D. (2012) New Forms of Sub-regional Governance and Implications for Rural Areas: Evidence from England. Planning Practice and Research, 27, 4, 441-458. DOI: 10.1080/02697459.2012.682476

Perraudin, F. (2017) Could God's own county win control of its own fate as 'One Yorkshire'? The Observer, [online] Available at: https://www.theguardian.com/uknews/2017/nov/12/one-yorkshire-calls-for-devolution-growing-louder [Accessed: 05/12/2017]

Pike, A. and Tomaney, J. (2009) The state and uneven development: the governance of economic development in England in the post-devolution UK. Cambridge Journal of Regions, Economy and Society, 2, 1, 13-34. DOI: 10.1093/cjres/rsn025

Pugalis, L., Townsend, A., Gray, N. and Ankowska, A. (2015) Planning for Growth: The Role of Local Enterprise Partnerships in England, Research Report No. 9. London: Royal Town planning Institute. Available at: http://www.rtpi.org.uk/media/1400949/rtpi research report planning for grow th final report 9 july 2015.pdf [Accessed: 05/12/2017]

Rodríguez-Pose, A. (2013) Do Institutions Matter for Regional Development? Regional Studies, 47, 7, 1034-1047. DOI: 10.1080/00343404.2012.748978

Sandberg, S. (2010) Finnish Power-Shift: The Defeat of the Periphery? In: Baldersheim, H. and Rose, L. (eds) Territorial Choice: The Politics of Boundaries and Borders. Basingstoke, Hants: Palgrave Macmillan, 42-60.

Sandford, M. (2012) Local authority shared services and mergers, Standard Note SN/PC/05950. London: Parliament and Constitution Centre, House of Commons Library.

Sarazhinsky, B. (2014) Local Governance in Belarus: The Impact of the Economic and Financial Crisis on the Administrative Division Reform. In: Nunes Silva, C. and Buček, J. (eds) Fiscal Austerity and Innovation in Local Governance in Europe. Farnham, Surrey: Ashgate, 129-141.

Shaw, K. and Greenhalgh, P. (2010) Revisiting the 'Missing Middle' in English SubNational Governance. Local Economy, 5-6, 457-475. DOI: 10.1080/02690942.2010.525999

Shutt, J., Pugalis, L. and Bentley, G. (2012) LEPs- Living up to the hype? The changing framework for regional economic development and localism in the UK. In: Ward, M. and Hardy, S. (eds) Changing Gear - Is Localism the New Regionalism? London: The Smith Institute, 12-24.

Sotarauta, M. and Beer, A. (2017) Governance, agency and place leadership: lessons from a cross-national analysis. Regional Studies, 51, 2, 210-223. DOI: 10.1080/00343404.2015.1119265 
p. 164. Cities and their hinterlands 10 years on: Local and regional governance still under debate

Thibert, J. (2015) Governing Urban Regions through Collaboration: A View from North America. Farnham, Surrey: Ashgate.

Townsend, A. (2012) The functionality of LEPs: are they based on travel-to-work? In: Ward, M. and Hardy, S. (eds) Changing Gear - Is Localism the New Regionalism? London: The Smith Institute, 36-44.

Wachsmuth, D. (2017) Competitive multi-city regionalism: growth politics beyond the growth machine. Regional Studies, 51, 4, 643-653. DOI: 10.1080/00343404.2016.1223840

Welsh Government/Llywodraeth Cymru (2017) Reforming Local Government: Resilient and Renewed. Cardiff: Welsh Government. 